\title{
14
}

\section{The Vietnamese state, the Catholic Church and the law}

\author{
Peter Hansen
}

In the village of Phuc Nhac, in the province of Ninh Binh, about 120 kilometres south of Ha Noi, stands a large whitewashed Catholic church. It is the worshipping centre of an active congregation drawn from the local population, more than 75 per cent of which is Catholic. Masses and devotional liturgies are frequent, well attended, and uninhibited.

In front of the church stands a small, somewhat neglected chapel, dedicated to the memory of St. Anna Le Thi Thanh (De), a Catholic laywoman martyred in 1841 under the emperor Thieu Tri, and canonised as a saint by the universal Catholic Church in 1988. The altar in the chapel bears the inscription

\footnotetext{
Sanguis martyrum est Semen Christianorum

The blood of the Martyrs is the seed of Christianity
}

This little tableau stands almost as an allegory of the present situation of the Catholic Church in Vietnam. Those who contend that the Vietnamese church enjoys total religious freedom justifiably point to the example of Phuc Nhac's thriving Catholic community, which goes about the articles of its faith-prayer, liturgy, sacraments, and catechesis-peacefully, unmolested and uninterrupted. The inscription in St. Anna's chapel, however, hints of another, different reality. The relationship between Catholicism and the state has through the long duree of almost 400 years, been fraught with conflict, mutual suspicion, antipathy, anti-Catholic persecution and martyrdom. The Vietnamese state has for centuries sought to use the law as a tool to regulate and control not only Catholicism, but other religions as well. 
Many Vietnamese Catholics now see the church as suffering exactly the same persecution it endured in centuries past, its clergy imprisoned, property confiscated, and its vital functions-such education of the clergy - tightly regulated. The law, they argue, is the means by which the present Vietnamese government seeks to slowly choke life from the church. Yet, perversely, they are often keen to embraceand perhaps even perpetuate-Catholicism's status as an embattled religion. The blood of the martyrs is, as the inscription tells us, the seed of the church.

Fundamentalist misconceptions bedevil understandings of the relationship between the church and the state. At one end of the spectrum is the view pushed by various Viet Kieu groups, that there is no freedom of worship at all for Vietnamese Catholics, making the practice of religion all but impossible. At the opposite end, the Communist Party of Vietnam and the Vietnamese government argue that the thriving and active church communities demonstrate the unfettered religious freedoms provided in Vietnam. The truth, as always, lies somewhere in between.

The relationship between the Catholic Church and the Vietnamese state is not governed well by the law, which remains a deeply imprecise and subjective instrument, capable of manipulation by either side. Similarly, while Marxist ideology has characterised humanity's religious/spiritual quest as illusory-famously, through the phrase 'the opiate of the masses' - this has not been the principal driver of the Party's or the state's attitude towards the Catholic Church. Although atheism remains the 'religious position' of Marxist ideology, and hence of the Communist Party of Vietnam, there is little to suggest that this ideological difference is the basis of their antagonism.

What factors, then, do govern the contemporary relationship between church and state? Historical antagonisms and earlier perceived wrongs continue to generate unease. Moreover, the Vietnamese church's desire to cast itself as a nationalist institution contradicts the state's desire to be the sole arbiter of the national history, the teller of the national story, and creator of national heroes.

But the law is an important instrument in the conduct of this historical-political conflict, capable of application and manipulation by both sides. I propose to examine certain aspects of the effects of Vietnamese law in the context of this debate and their effects on the operation of the Vietnamese Catholic Church as a religious and social institution. ${ }^{1}$

\section{THE CONSTITUTIONAL CONTEXT}

Article 70 of the 1992 Constitution of the Socialist Republic of Vietnam provides that

[t]he citizen shall enjoy freedom of belief and religion; he can follow any religion or follow none. All religions are equal before the law. The places of worship of all faiths and religions are protected by the law. No one can violate freedom of belief and of religion, nor can anyone misuse beliefs and religions to contravene the law, and State policies. ${ }^{2}$

Provisions guaranteeing religious freedom have formed part of every constitution since Ho Chi Minh's declaration of independence in $1945 .{ }^{3}$ Indeed, Ho declared on 
the first day after the promulgation of the declaration that 'the colonialists and feudal regime carried out [a] policy of division between our religious and non-religious compatriots with a view to facilitating their domination. I propose that the government declare religious freedom and unity between religious and non-religious people'. ${ }^{4}$

The unequivocal constitutional declaration that 'the citizen shall enjoy freedom of belief and religion' seems to support the Vietnamese government's oft-repeated claim that its legal system provides and enforces a regime of religious freedom and tolerance. Yet, dissenting voices contend that the provision is in reality a frail shield, so easily ignored, contradicted, and compromised by other provisions that it is rendered entirely hollow and meaningless. Where, then, does the truth lie?

\section{THE CONSTITUTIONAL GUARANTEE AS EFFECTIVE}

Even critics of the Vietnamese government concede that ordinary Vietnamese Catholics now enjoy reasonable freedom to attend liturgies and services at their places of worship (cf. Tran Xuan Tam 2002). Although Catholics may still face some discrimination at the local level from party or state functionaries seeking to restrict active church participation, the ordinary lay worshipper is nowadays seldom a direct victim of government restrictions. The views expressed to an Agence-France Presse journalist in April 2000 seem representative

In Hanoi, the country's capital, as worshippers packed St. Joseph's Cathedral for Sunday services, Nguyen Thi Minh said how proud she was to be a Catholic. Minh, 58, said Vietnam's Catholics were free to practice their religion, but she was quick to point out that they still face discrimination. 'Although we are patriotic, Catholics have less opportunities to take important positions in society and in the armed forces. I hope this will improve in time', he said.

Another church attendee, a 22-year old girl who asked not to be named, said plainclothes police still often monitor church services. 'All members of my family are Catholics, and I feel free to follow the Church, although I sometimes see plainclothes police walking around here at church services'.

She added that Catholics still suffer from some stigma because of their association with the old Saigon regime, but she added that this was changing fast. 'I am happy to be Catholic, although sometimes it restricts my social relations,' she said. 'Some people are still careful about making friends with Catholics, because my father told me that during the wars, many Catholics followed and worked for enemies. But this complex is disappearing fast' (de Nerciat 2000).

Some critics of the government deride the significance of such 'superficial' liberty as nothing more than a smokescreen concealing the deprivation of any meaningful religious freedom. But such derision not only negates the government's view; it also infers that Vietnamese Catholics who feel their spiritual needs are currently being met (such as those quoted above) are deluded.

Article 70 is not entirely inconsequential. Whatever religious freedoms presently exist in Vietnam can be at least partly attributed to the constitutional protection offered by the article. 
An important illustration of this constitutional protection is the tolerance granted to the local church's continued communion with the universal Catholic Church through allegiance to the Papacy. Although the connections between the Catholic Church in the Democratic Republic of Vietnam and the outside world were effectively cut between 1954-75, the Vietnamese state never required its citizens to renounce spiritual allegiance to the Vatican. In 1955, the government oversaw the establishment of an association of pro-government Catholic laity and clergy, the Uy Ban Lien Lac Cong Giao Yeu To Quoc va Hoa Binh [Liaison Committee of Patriotic and Peace-loving Catholics] (Denney 1990). This body became the Catholic affiliate to the Mat Tran To Quoc [Fatherland Front] and usurped many of the normal entitlements of the episcopal hierarchy, particularly in the realm of spokesmanship of the church. It still fulfils this role, although it has been known since 1983 as the Uy Ban Doan Ket Cong Giao Yeu Nuoc Viet Nam [The Solidarity Committee of Patriotic Vietnamese Catholics]. However, the association never set itself up as a church per se; it was always viewed by the state as an association that Vietnamese Catholics could join while remaining loyal in the spiritual realm to the established church. ${ }^{5}$ Crucially, neither the government nor the 'Patriotic Association' made any endeavour to establish a parallel, statecontrolled church, by ordaining bishops not in communion with Rome. The contention often made that the Vietnamese state claims the right to appoint bishops is incorrect. ${ }^{6}$ Whilst they claim a veto right over Vatican appointments, and have on many occasions in the past exercised that veto in rejecting candidates proposed by the Vatican, they have never sought to ordain candidates not endorsed by the Vatican.

In this regard, the history of the Catholic Church under the Communist regime in Vietnam is radically different to that in the People's Republic of China. In 1958, the Chinese government first arranged for bishops to be validly but illicitly ordained; that is, consecrated by other validly ordained bishops, but without the approval of Rome (Tong 1993). ${ }^{7}$ These bishops then pledged allegiance to the Chinese state and abjured allegiance to the Pope. Chinese Catholics were called on to follow this new 'Patriotic Church', with its parallel episcopacy, out of communion with the Vatican. Bishops, priests and laity who continued to profess communion with Rome-a profession deemed inconsistent with membership of the 'Patriotic Church' - were committing a punishable criminal offence and became known as the 'Underground Church' (Tong 1993).

To an outsider, these matters canvassed may appear semantic, pedantic, and inconsequential, but from a Catholic perspective, they are of the deepest significance. The Catholic Church believes that the gravest fate that can befall it is schism; that is, the division of the church. Schism threatens its universality, and thus its deepest sense of identity. Whereas religious persecution is to be endured (and perhaps even profited from), two millennia of church history provide innumerable examples of how the body of the church has been irreparably damaged by schism. In this respect, the church mirrors Vietnamese self-perceptions, whereby mat doan ket dat nuoc [loss of national unity], is amongst the most serious of allegations that can be levelled against history's less favoured monarchs. 
What has all this to do with the Vietnamese Constitution? On one level, the original decision to permit Vietnamese Catholics' continued spiritual affiliation to Rome-almost certainly made by Ho Chi Minh himself-was a political decision, made to assuage Catholics, and to enlist their support for the post-colonial regime. Catholics have for three centuries formed a much larger and more influential segment of the Vietnamese population than in China. Moreover, Ho had successfully sought to ensure that Catholics were well represented in the broad coalition of social and political forces that comprised his government in $1945-46 .{ }^{8}$ There is no doubt that these political considerations informed the constitutional assurance of religious freedom currently embodied in Article 70.

But the constitutional provisions also have their own efficacy. Any subsequent attempts to start a state-sponsored church-as opposed to an association of Catholic believers-and to forbid communion with Rome (as happened in China), would have been in flagrant breach of the state's own constitutional provision. In other words, the constitutional guarantee of religious freedom bolstered the Vietnamese church's capacity to preserve its most treasured asset-its membership of the universal Catholic Church. It is therefore difficult to sustain the argument that Article 70 is entirely worthless and devoid of meaning for Vietnamese Catholics.

\section{THE CONSTITUTIONAL GUARANTEE AS INEFFECTIVE}

At the same time, the contrary proposition-that Article 70 is evidence of the uncompromised nature of religious freedom in Vietnam-is similarly difficult to sustain. Its efficacy is compromised by internal inconsistencies within Article 70 itself, by inconsistencies between Article 70 and other constitutional provisions, and by inconsistencies between Article 70 and other Vietnamese laws.

Statutory interpretation of Article 70 indicates that its guarantee of religious freedom is not absolute, but qualified. The article's provision that no one can misuse beliefs and religions to contravene the law and state policies must be interpreted as derogating from an absolute guarantee. The phrase 'misuse of beliefs and religions' is indeterminate and susceptible of many interpretations. Could some ordinary religious functions, such as the Catholic engagement in social justice and advocacy for human rights, be regarded as a 'misuse of beliefs and religions'? The Catholic Church has long seen engagement in social advocacy, including support for the marginalised and opposition to structural injustice, as a fundamental role, entrusted to it by Jesus Christ as part of its emulation of his earthly mission. Yet, there is every chance that the state would interpret any endeavour by the Vietnamese church to fulfil this apostolic function as a 'misuse of beliefs and religions' under Article 70.

Article 70 provides no criteria as to what is considered a 'misuse', nor does it state who is to be the arbiter of whether a particular activity falls within the definition. Arguably, it was the constitutional drafters' intent that the determinative power rest with the Vietnamese state, with the church itself having no role to play. This 
potentially grants to the state the effective capacity to circumscribe what constitutes legitimate religious activity, and axiomatically, to place outside the bounds of legitimacy whatever it finds displeasing. This is not to say that the Vietnamese Party and state will always exercise this power in an arbitrary or totalitarian manner; after all, it currently tolerates a great many religious activities, which it probably wishes were not happening. Nonetheless, the connection within Article 70 between the concepts of 'misuse of religion' and 'contravening state policy', without causality, is of some concern. It suggests that religious legitimacy is contingent on congruence with the political and administrative aims of the ruling party. Taken to its logical conclusion, this renders religious activity an instrument of state policy; as, indeed, many statements from party and government spokespeople proclaim it to be. Such a view is so incompatible with the church's theological and ecclesiological selfperceptions as to render it permanently unacceptable to the church.

Reading Article 70 in the context of the constitution as a whole does little to improve the situation. Several other constitutional provisions may also be read as compromising Article 70's efficacy. As with Article 70 itself, their often benign appearance is compromised by qualifications or exceptions which render the provisions ineffective, or even retrograde, in the hands of any government with malevolent intent.

One constitutional provision often cited as an impediment to religious freedom is Article 4, which enshrines the leading role of the Communist Party of Vietnam. It states that

[t]he Communist Party of Vietnam, the vanguard of the Vietnamese working class, the faithful representative of the rights and interests of the working class, the toiling people, and the whole nation, acting upon the Marxist-Leninist doctrine and Ho Chi Minh's thought, is the force leading the state and society. All Party organisations operate within the framework of the Constitution and the law.

This provision no doubt gives succour to anticommunist antagonists who would view the Vietnamese Constitution in an 'instrumentalist' context. Professor Mark Sidel, in his analysis of the Vietnamese Constitution, described instrumentalism thus

[t]he instrumentalist theory is relatively clear-cut: Constitutions in Communist-Party run socialist countries have been, and remain, a means of political control by a single party, a way of expressing Communist Party political, economic and social policy in constitutional terms, a method for mobilising action, and a malleable document subject to redrafting and adoption by a compliant legislature as times and policy changed (Sidel 2002:42). ${ }^{9}$

The Special Rapporteur on Vietnam, Abdelfattah Amor, in his 1998 Report to the United Nations Commission on Human Rights, adopted a largely instrumentalist stance in considering the possible ramifications of Article 4 on religious freedom

[e]ven greater concern is raised by Article 4 of the Constitution, which sets forth the principle of the Communist Party of Vietnam as the 'guiding force' of the state and of society. State policies are therefore those of the Communist Party, which has its own ideology with regard to religion, initially perceiving religion to be the opium [sic] of the people and therefore to be combated, and later evolving toward a special recognition of religion... 
Whatever the ideology, the Special Rapporteur is of the opinion that, from the international law standpoint, the problems involved are similar to those of a State religion. If, for the sake of analysis, we take the Communist ideology as the 'state religion', the problems, in terms of international law, is not seen in relation to that given, but in terms of its manifestations. It is essential that that given should not be used to undermine human rights, in particular freedom of religion or belief (Amor 1998:paras 103-4).

If one takes an instrumentalist view of the Vietnamese Constitution, then its enshrinement of the Communist Party's primacy can be seen as having adverse implications for religious freedom, especially when that freedom might be used to the detriment of the Party's exercise of power.

However, 'state ideology' is not the same as 'state religion', and Amor is misguided in equating the two. To the contrary, the Party has always been emphatic in insisting that religion has no role to play in the development of state policy, nor the ideology on which it is based. There is, therefore, no theoretical inconsistency between a state political ideology, and the tolerance of religious pluralism. Ideology has never been the primary ground of contestation between the Communist Party of Vietnam and the Catholic Church. Party criticisms of the church seldom, if ever, make negative reference to Catholic theology, doctrine, or dogma. Exposition of the classical Marxist position on organised religion can nowadays only be found in obscure theoretical journals. And, as noted above, those same journals now sometimes endeavour to explain away Marx's views on religion as limited to a given historical-political context. Instead, Party/state criticism of the church concentrates on its historical antecedents, particularly its association with the French colonisation of Vietnam. While Article 4 has a considerable influence on the overall question of democratic pluralism within Vietnam, its influence on the position of the Catholic Church is largely theoretical. ${ }^{10}$ The potentially more significant provision in terms of a constitutional threat to religious freedom is the punitive Article 13, which provides that

[t]he Vietnamese motherland is sacred and inviolable. All machinations and acts directed against the independence, sovereignty, unity and territorial integrity of the motherland, against the construction and defence of the socialist Vietnamese motherland, shall be severely punished in accordance with the law.

Although this provision refers specifically to the state-in contrast to Article 4's reference to the Party-the tight symbiosis between the contemporary Communist Party of Vietnam and the state makes it likely that threats against the Party are seen as threats also to the 'socialist Vietnamese Motherland'. Yet there is no suggestion that the practice of religion is in any way contextualised as a 'machination directed against' sovereignty. Provisions of the criminal code guarding national security have been employed against a notable Catholic dissident, Fr. Thaddeus Nguyen Van Ly, although the suggestion that his 'actions against national unity' were of a religious nature is open to question.

Another significant provision is Article 30, which covers the protection of national culture. The article concludes that 'the propagation of all reactionary and depraved 
thought and culture is forbidden; superstitions and harmful customs are to be eliminated'. The use of the term me tin ('superstition') is, again, typical of the ambiguity prevalent in Vietnamese constitutional and legislative practice. What does 'superstition' mean? How is it to be distinguished from religion? Who will judge this delineation, and what methodology will they use?

There is no suggestion that the Vietnamese government has recently used 'antisuperstition' provisions against mainstream Catholic religious practice. ${ }^{11}$ Article 247 of the 1999 Penal Code gives some guidance as to how 'superstition' is to be viewed-'Exercise of superstitious practices: any person who practices divination, acts as a medium, or pursues other superstitious practices... ${ }^{12}$

There remains a concern that legitimate religious activity may wrongly be regarded as 'superstition'. A Party statement in April 2003 declared that

[t]he Party also recognises that there are many complicated matters in religious practices, which will create disorder and instability, and endanger national security. Many people and illegal preaching groups are taking advantage of local people's beliefs to increase superstition and disseminate hostile attitudes to erode great unity among the peoples ('Party publicises policies on religion and faith', Vietnam News Briefs, 25 April 2003). ${ }^{13}$

There is also a worrying prospect for overlap, whereby religious activities considered legitimate by the church nonetheless attract official approbation as 'superstition'. This problem most recently arose in 1998 at the 200th anniversary of the Marian apparition at La Vang. Vietnamese Catholics revere La Vang, a small village in central Quang Tri province, where in 1798, the Blessed Virgin Mary is said to have appeared to a group of poor woodcutters. Each year, on 15 August-the feast of Our Lady of La Vang-Catholics from all over Vietnam gather at the apparition site to venerate, commemorate, and celebrate these events.

Not surprisingly, the 200th anniversary celebration in 1998 saw even larger crowds than usual. The gathering of an enormous crowd not immediately under government auspices and control caused officials considerable consternation, ${ }^{14}$ which was no doubt exacerbated by the political undertones of the La Vang apparition. The original events had occurred at a time of significant anti-Catholic persecution. The political message of the apparition-implied but unspoken in the current era-is not to lose heart in the face of state oppression, for the power of the divine remains with believers. These quasi-political implications troubled the Vietnamese government and, together with the event's tinges of superstition, prompted then Party Secretary, Le Kha Phieu, to claim that 'thrift is more important than festivals during difficult economic times' (Soloman 1998:n.p.). In other words, the La Vang anniversary did not fulfil a legitimate religious purpose. ${ }^{15} \mathrm{~A}$ rationalist or utilitarian view can always find 'superstition' in religious ritual, and, while this has not yet occurred overtly, the provision remains a potential weapon if the Vietnamese government should decide on a more aggressively anti-Catholic stance.

No other constitutional provisions refer directly to religion, but several have a potential impact on religious freedom. For example, Article 33, which bans 'all 
activities in the fields of culture and information that are detrimental to national interests, and destructive of the personality, morals and fine lifeway [sic] of the Vietnamese', effectively provides a justification for limiting the church's ability to publish materials not in conformity with Party/state precepts. As will be seen in the next section, this justification is used extensively to ensure that the church-like other non-state institutions-has limited access to publishing and media.

Finally, there is a group of provisions concerning the duties of the citizen within the Vietnamese state that may also have ramifications for the practice of religion and citizens' religious rights. For example, Article 51 provides that

[t]he citizen's rights are inseparable from his duties. The State guarantees the rights of the citizen; the citizen must fulfil his duties to the State and society. The citizen's rights and duties are determined by the Constitution and the law.

Articles 76-79 provide that

76. The citizen must show loyalty to his motherland. To betray one's motherland is the most serious crime.

77. It is the sacred duty and the noble right of the citizen to defend his motherland. The citizen must fulfil his military obligation and join in the all-people national defence.

78. The citizen has the duty to respect and protect the property of the State and the public interest.

79. The citizen has the duty to obey the Constitution and the law, join in the safeguarding of national security and social order and the preserving of national secrets, and abide by the regulation of public life.

The above provisions are arguably capable of bearing a benign interpretation. Their cumulative effect, however, is to provide that the citizen's first duty is always to the state, so that where an individual's duties to church and state conflict, duty to the state must prevail. ${ }^{16}$ This is not simply a hypothetical prioritisation. The Vietnamese state often stresses to Catholics that they are 'Vietnamese first, Catholics second'. This contradicts the Catholic Church's claims over the supreme allegiance of its adherents and thus bears potentially significant practical consequences. For instance, in the 1970s and 1980s, it was quite common for Catholics to be compelled to undertake corvée labour on Sundays, sometimes thereby preventing them from fulfilling their Mass obligations. ${ }^{17}$ That the primary claim of church and state over Vietnamese Catholics focuses on notionally separate realms- the secular and the spiritual respectively - does not necessarily resolve the matter. For example, Vietnam has one of the highest abortion rates in the world, which can be at least partly attributed to the population control policies of the Vietnamese government (Haub and Phuong Thi Thu Huong 2003). How then can the church advocate its traditionally strident anti-abortion stance without contravening government policy? And on what basis should individual Vietnamese Catholic women make their personal choice? ${ }^{18}$ 
People the world over face potential conflicts between their religious and civic duties as citizens, but the cumulative effect of the constitutional provisions referred to above goes beyond this to effectively compel citizens to prioritise their duties to the state. Moreover, where the state is essentially conflated with a political party that harbours historical antagonisms and suspicion towards the church, the potential for conflict between religious and civic duties becomes all the more acute.

\section{THE LEGISLATIVE CONTEXT}

\section{Ambiguity and resolution}

The Catholic Church, well-organised and accounting for 6-10 per cent of the Vietnamese population, has always represented a significant potential challenge to the Party and the Vietnamese state. ${ }^{19}$ The state deals with the Church not by seeking to eliminate it, but rather by regulating, circumscribing, and hence controlling it. It maintains a similar attitude to other religions. Antagonists of the current regime claim that, in so doing, the state hopes that the church will ultimately wither at the roots and die. The government, for its part, argues simply that it requires the church to follow the example of all other social institutions by submitting to the requirements of the law.

The legal regulation of religious affairs is nowadays principally embodied in Government Decree 26/1999, promulgated on 19 April 1999. It is in turn based on a directive of the Communist Party (No.37 CT/TW), issued on 2 July 1998, which directs the state to pursue a policy of regulatory control

[t]he government will issue detailed provisions and guidance on the activities of religious orders and associations, fund-raising, financial operation, humanitarian and charitable actions, cultural and artistic activities, external relations, land use, building and repair of places of worship, training of clerics and religious dignitaries, and other activities of religions in conformity with the existing policies and laws. ${ }^{20}$

The Party's insistence that the state regulate religion is reflected in the preliminary provisions of the decree

(3) Religious activities must obey the law of the State of the Socialist Republic of Vietnam.

(4) Religious activities in the legitimate and lawful interests of the believers are assured. Religious activities in the interests of the Motherland and the people are encouraged.

(5) All acts of violation of the freedom of belief and religion, all acts of misusing belief and religion to oppose the State of the Socialist Republic of Vietnam, prevent believers from discharging their citizens' obligations, sabotage the cause of unity of the entire people, and harm the healthy culture of the nation, and all superstitious practices, shall be dealt with according to law (Nguyen Minh Quang 2001:136).

All of the comments made above concerning the amorphous, general, and openended wording of constitutional provisions apply equally to these quasi-legislative 
provisions. How, for instance, does one define 'citizen's obligations' or 'the healthy culture of the nation'? If we were examining such legislative provisions within the context of common law systems, such as Australia's, such ambiguity could be resolved in a number of ways. First, one could look to definitional clauses that might further elaborate upon the meaning of the phrases adopted in the legislation. Second, recourse may be had to legal precedents, either binding (ratio decidendi) or persuasive (obiter dicta), indicating how the subject provisions had previously been interpreted by the courts. Or, in the absence of either of these aids, the courts can interpret the provisions, particularly to decide whether they were ultra vires by infringing on any express or implied constitutional guarantees or protections. None of these tools of statutory interpretation are currently used to any great extent in Vietnam. ${ }^{21}$

Further, the lack of a Constitutional Court, in particular, has been a matter of some recent controversy. The system provides no real means either to interpret legislative and quasi-legislative instruments or to adjudicate on their constitutionality.

In 2001, a Ho Chi Minh City newspaper carried a call from a delegate to the National Assembly 'for the establishment of a Constitutional Court [Toa An Hien Phap] to defend the Constitution....against the many forms of constitutional violation that at present cannot be investigated or adjudicated' (quoted in Sidel 2002:79). Legal scholar Nguyen Van Thao was even more direct in his criticism of the lack of judicial oversight

[i]n nearly ten years of Constitutional implementation, we have never once seen the National Assembly or its Standing Committee abrogate, cancel, or suspend the implementation of a single document issued by the President, the government, or the Prime Minister. The system of monitoring is almost never exercised by the government or the Prime Minister with respect to the ministries or local authorities, despite the fact that some legal documents issued by ministries and local authorities evidently violate the Constitution or laws (quoted in Sidel 2002:71).

Such lack of resolution methods renders the laws and their interpretation more susceptible to manipulation on the part of an omnipotent state. Many would suggest that this is exactly what has occurred in relation to the Vietnamese government's regulation of religious affairs. Certainly, the specific regulatory controls imposed by the subsequent provisions of Decree 26 form the basis of many Catholic complaints about restrictions on the church's ability to operate freely as a religious institution.

\section{The specifics of regulation}

Chapter 2 of Decree 26 provides for the specific aspects and modes of state regulation of religion. Many of these provisions have drawn criticism as constituting a de facto impediment to true religious freedom.

Most fundamentally, all religions and religious denominations must seek the permission of the Prime Minister in order to operate legally.22 Article 8 (5) provides that religious organisations 'which act in variance with the principles, objectives, 
line of worship and organizational structure permitted by the Prime Minister shall have their operations suspended'. Under Article 8(2), religious activities (for example, liturgies, prayers services, sermons, catechetical teachings) must be licensed annually or given specific permission per event under Article 8(3). Article 8 (4) provides that those undertaking religious fundraising activities must be licensed by local People's Committees. Further, according to Article 12, repairs to religious buildings, and fundraising for such repairs, can only be undertaken with state approval. Retreats and 'similar religious activities' must be in accordance with government regulations under Article 9; religious conferences must have state approval (Article 10). Finally, Article 14 provides that the printing, publication and the importation of publications and 'religious cultural articles' is to be regulated by the state. ${ }^{23}$

The formation, ordination, and activities of the clergy are also regulated. Persons unlicensed by the state cannot claim to be, or function as, religious clergy (Article 16). Seminaries must be licensed by the prime minister (Article 18(1)), and their activities supervised and inspected by state agencies (Article 18(3)). The bestowal of religious titles (for example, bishop, cardinal) requires the permission of the prime minister (Article 20), thus providing a de facto government veto over episcopal appointments. At a lower level, the appointment and transfers of clergy (to parishes, seminaries, agencies) must be approved by local People's Committees (Article 21). Clergy are obliged 'to carry out exactly their functions and roles in the domain of their religious responsibility already approved by the competent state management agency' (Article 15(2)). Religious orders must seek state permission to operate (Article 19(1)), whilst admission into monastic life must conform with the stipulations of the State Religious Affairs Committee (Article 19(2)).

The existence of religious charitable establishments and associations, while not prohibited, must 'operate under the guidance of competent state authorities' according to Article 17(2). The Vietnamese Catholic Church maintained significant welfare and educational infrastructures under pre-Communist regimes, and is now slowly re-establishing its presence in the sector through licensed activities in accordance with the article. Permission is still frequently withheld, however, and local authorities can effectively countermand permission granted by the State Religious Affairs Committee.

Given its particular connection to the Vatican, and the universal Catholic Church in general, the articles regulating foreign religious involvement are of particular importance to the Vietnamese Catholic Church. Religious organisations' international activities must comply with state policies and precepts (Article 23), and such organisations must advise the Religious Affairs Committee of any instructions received from 'foreign religious organisations', and then comply with any instructions issued by the committee (Article 22). Invitations to 'foreign religious organisations and individuals' must be approved by the Committee for Religious Affairs in accordance with Article 24. Foreigners wishing to undertake religious activities in Vietnam must register with local People's Committees (Article 25), and 
any aid received from foreign religious organisations must be approved by the State Religious Affairs Committee (Article 26).

\section{Application of the decree}

Whilst the situation of the Catholic Church has improved in recent years, and the overall trend has been towards greater liberalisation, these articles are not merely 'on paper' provisions. They are actively applied to control the Catholic Church and regulate its activities. The nomination of bishops, which requires prime ministerial permission under Article 20, was frequently thwarted, resulting in dioceses remaining vacant, sometimes for many years (cf. Brunnstrom 2000). ${ }^{24}$ This situation has improved significantly over recent years, so that few Vietnamese sees now remain vacant. Local 'People's Committees' have used the decrees to refuse permission for priests to be appointed to parishes, or for churches to be built (cf. 'Vietnamese Catholics cite persecution amid success', Fides, 6 March 2000). Whilst the situation regarding the training of seminarians and the ordination of new priests has greatly improved recently, each of the six Catholic diocesan seminaries is restricted to only twenty students every two years. Admission of students to the seminary, and subsequent ordination, is dependent on their being vetted by the 'Religious Affairs Committee' ('An interview with Joseph Nguyen Cong Doan', America, 23 October 1999). This stringent requirement has led to severe shortages of clergy in some dioceses.

Restrictions on publishing are also actively enforced. For example, an attempt on the part of the 'Episcopal Conference' to publish its own permanent bulletin was quickly thwarted when permanent publishing permission was denied (Tran Cong Nghi 2001). ${ }^{25}$

As strident as church complaints have been concerning these particular provisions, they are in one sense all subordinate to the overarching provision that religions must be registered, and hence licensed by the state. The requirement that religious activity be approved by the state effectively limits the constitutional guarantee of religious freedom, confining it to a freedom to practice only statesanctioned religion. In its 2000 'Report on Religious Freedom in Vietnam', the Bureau of Democracy, Human Rights and Labor of the US State Department concluded that

[t]he government requires religious groups to register, and uses this process to control and monitor church organisations. The granting or withholding of the official recognition of religious bodies is one of the means by which the Government actively intervenes to restrict religious activities by some believers (Bureau of Democracy, Human Rights, and Labor 2000).

The Vietnamese government defends the licensing provisions, claiming that they assist in protecting religious freedom

Virtually, 'freedom' and 'permission' in their proper sense are not contradictory. Across the globe, maybe no law-ruled state would demolish the administrative procedure of 'request for permission', which helps society differentiate between legal and illegal undertakings. 
And the most important principle in this issue is that the State and law protect, guarantee and safeguard legal undertakings. 'Request for permission' is aimed to obtain permission, and permission entails the 'right to protection'. Therefore, failure to request for permission is tantamount to relinquishing a very valuable right; the right to be protected. Then, in what way is 'request for permission from the State' abnormal? (Nguyen Minh Quang 2001:117-8).

The answer to that rhetorical question lies in the falsity of the assumption that religious activity lying outside of the state purview should be regarded as illegal.

When religious figures seek to place themselves in conflict with the Vietnamese state over questions of religious freedom, however, the state does not use decrees on religion, opting instead to punish such behaviour through the criminal law. Both sides of the debate have sought to manipulate this use of the criminal law to their own advantage.

\section{The criminal law context}

Some aggrieved Viet Kieu observers accuse the Vietnamese Catholic Church—and especially its bishops - of being supine in the face of governmental pressure (cf. Tran Xuan Tam 2002). But there have always existed religious figures who, instead of striving for accommodation, consensus and agreement between the church and the state, challenge the status quo, and condemn what they perceive to be unfair treatment meted out to their religion. It is these religious dissidents that the provisions of the criminal law seek to affect. ${ }^{26}$ It should be remembered, however, that such dissidents constitute only a small proportion of religious practitioners in Vietnam; most manage to find a way of operating under the regime, albeit sometimes an uncomfortable one.

Almost invariably, when criminal charges are laid against religious dissidents, they are made under the provisions of Chapter XI of the 1999 Criminal Code, which deals with the violation of national security. Some of the offences in Chapter XI are clearly defined and well understood in any developed legal system - treason (Article 78), espionage (Article 80), rebellion (Article 82), piracy (Article 83), and terrorism (Article 84).

Other provisions, however, are ill-defined and ambiguous, generating situations whereby actions that are currently outlawed would not necessarily be seen as criminal in other socio-political contexts. This in turn leads to allegations that these provisions are actively manipulated to achieve desired political or administrative outcomes. These amorphous provisions include 'activities aimed at overthrowing the People's power' (Article 79); 'sabotaging the infrastructure of socialism' (Article 85); 'undermining national unity' (Article 87); 'propaganda against the socialist system' (Article 88); 'endangering public security' (Article 89); and 'illegally fleeing to or staying in another country with intent to undermine the People's power' (Article 91).

The following case study, involving a well-known Catholic dissident, addresses the use of one of these provisions, namely Article 87. 


\section{THE CASE OF FR. THADDEUS NGUYEN VAN LY}

Fr. Thaddeus (Tadeo) Nguyen Van Ly was born in Quang Tri Province in 1946, and ordained as a priest of the Archdiocese of Hue in 1974. He subsequently served as secretary to the Archbishop of Hue, Phillip Nguyen Kim Dien, himself an ardent critic of the Vietnamese government and campaigner for religious rights, who died in 1988. Ly had already served 10 years' incarceration; one year of cai tao ('reeducation') from 1977 to 1978, and nine years' imprisonment (1983-92) for 'opposing the revolution, and destroying the People's unity' (see 'Archbishop calls for release of Viet priest', Catholic Weekly (Sydney), 5 September 2001). Some time after being released, he was appointed to Nguyet Bieu, a small and impoverished parish of about 150 Catholics on the outskirts of Hue city.

According to the 'Free Vietnam Alliance' (not, it must be said, an impartial source), the current problems of Fr. Ly and his parishioners began in 2000, in a dispute with local authorities over confiscated land

Soon after 1975, the Nguyet Bieu parish lost to the local agricultural commune $10,000 \mathrm{~m}^{2}$ of rice-growing land and $5,000 \mathrm{~m}^{2}$ of dry land, including $1905 \mathrm{~m}^{2}$ within the perimeter of the church. According to Order 297/CP, issued on November 11, 1997 by the Government, the commune must return the entire area of $1905 \mathrm{~m}^{2}$ of rice-growing land for compensation. In reality, however, the commune returned only $250 \mathrm{~m}^{2}$ of rice-growing land, and $250 \mathrm{~m}^{2}$ of pond surface. Not only that, it usurped an additional $200 \mathrm{~m}^{2}$ of land inside the church perimeter for an irrigation canal. After submitting many complaints to the local government for redress without results, the parishioners of Nguyet Bieu decided to redirect the irrigation canal around the church perimeter so that they can cultivate the lands inside of the perimeter as a source of income for the church's religious activities.

In 16-20 November 2000, Public Security cadres arrived and prevented parishioners from removing the soil to the area to build the new canal. The people of the parish, however, continued to prepare the land beside the church perimeter for the coming growing season.

On 4 December 2000, parishioners of Nguyet Bieu planted a large banner with the words 'We need freedom of religion' on the Church's land, in an attempt to intimidate Father Nguyen Van Ly. They uprooted the banner and threw it into the nearby pond...27

The scope of Fr. Ly's aggrieved response went far beyond issues pertaining to the unjust confiscation of parochial land. On 20 December 2000, he issued a statementwidely circulated by Viet Kieu sources-along with a subsequent letter to Pope John Paul II and other dignitaries on 11 January 2001, both of which condemned the Vietnamese government for its alleged suppression of the Catholic Church, its intolerance of religion, and its abrogation of the Vietnamese Constitution. ${ }^{28}$ However, his most controversial and most internationally publicised criticism of the Vietnamese state came in a letter of testimony to the Commission for International Religious Freedom of the US Congress. At the time of the presentation-13 February 2001-two events of considerable political importance and sensitivity were in prospect. The first was the Ninth Party Congress, which was due to commence the following May. The second was the pending signature and ratification of a bilateral trade agreement between Vietnam and the United States. Fr. Ly, in his overall 
condemnation of the Vietnamese Communist Party/state, chose to address explicitly the issue of the trade arrangement

....The second matter that you would like me to contribute my ideas to is whether or not the US Congress will go ahead to pass the bilateral trade agreement (BTA) this Spring? How will this passing affect freedom of religion in Vietnam?

I am only a priest, not specialising in trade and politics. I only stand on the viewpoints of a Vietnamese who loves my country enthusiastically, and is concerned about the human rights situation for my compatriots. I would like to contribute my simple ideas as follows:

Vietnam is deeply in need of the BTA to develop its economy. In principle, I earnestly wish my country to win other nations' trust, among them the US, in order that it may soon move to prosperity, and my compatriots enjoy a civilised and developed society in all aspects.

But if the Vietnamese communists continue to maintain a totalitarian dictatorship, do not respect the basic rights of citizens...then should the United States and other countries create more favourable conditions for Communist Vietnam to continue its dictatorial rule? It is only a minority group who will benefit from new conditions to prolong their power, and to the detriment of our miserable people, who get little from the BTA, and have to endure their fate under long-term oppression.

(...) Therefore, if the US and other nations truly love our miserable people, are truly concerned about human rights, especially freedom of religion in our country, then the U.S. and other nations should not support the Vietnamese communists to prolong their totalitarian dictatorship. On the contrary, the U.S. and others should stop the Agreements [i.e., the BTA] that the Vietnamese communists abuse, and find ways to put hard pressures on them to bring about freedom and democracy for Vietnam (Nguyen Van Ly 2001b:n.p.). ${ }^{29}$

The reaction of the Vietnamese authorities to this highly provocative advocacy was swift. After receiving reports from the District People's Committee dated 14 February (the day after Fr. Ly's written congressional testimony) and the Provincial Advisory Council, the Provincial People's Committee of Thua Thien-Hue Province issued a decision on 26 February 2001, subjecting Fr. Ly to administrative detention (in effect, house arrest) pursuant to Directive $31 / \mathrm{CP} .{ }^{30}$ Directive $31 / \mathrm{CP}$, promulgated in April 1997, authorises village-level People's Committee and Public Security officials to detain individuals without trial for between six months and two years (Human Rights Watch 1997). Article 2 of the Directive states that

[a]dministrative detention applies to those individuals considered to have violated the laws, infringing on the national security, as defined in Chapter 1 of the Criminal Code, but [whose violation] is not serious enough to be prosecuted criminally (Human Rights Watch 1997).

There is notable concern about this article, as Human Rights Watch points out, 'because there is no criminal prosecution [under Decree 31/CP], the detainee is not brought to trial, and therefore there is no opportunity for legal defence' (Human Rights Watch 1997).

The Notice of Decision to detain Fr. Ly provided only a brief description as to why the detainment had been imposed.

Reason for administrative detainment: Citizen Nguyen Van Ly has committed actions in violation of the laws, and harmful to the national security. However, it is considered that 
Mr. Ly should be given time to be educated and favourable conditions to correct his mistakes. The administrative detainment is, therefore, needed as specified by the current regulations. ${ }^{31}$

It seems Fr. Ly chafed at the restrictions that administrative detention placed on him, and he soon faced charges under the criminal code for breaching the terms of his administrative detainment and for having 'undermined national unity'. He was arrested in mid May 2001 and brought to trial on 19 October. After a half-day trial, he was sentenced by the People's Court of Thua Thien-Hue Province to consecutive sentences of two and thirteen years respectively, with a further five years of home detention thereafter ('Vietnam jails priest for 15 years', Reuters, 20 October 2001). ${ }^{32}$ He was released into house arrest as part of the New Year amnesty of 2005. The charge that he had 'undermined national unity' was laid pursuant to Article 87 of the 1999 Vietnamese Criminal Code, which provides that

(1) Any person committing any of the following acts with intent to undermine the people's power shall be subject to a term of imprisonment of between five and fifteen years.

a. Sowing division amongst social strata, or between the people and armed forces, and the people's power and social organisations;

b. Sowing hatred, discrimination and division, and committing infringements of equal rights among the different ethnic groups in Vietnam;

c. Sowing division between religious believers and non-believers, between the former and the people's power and social organisations;

d. Undermining the implementation of the policy of international solidarity.

(2) If the offence is committed in less serious circumstances, the offender shall be subject to a term of imprisonment of between two and seven years.

Neither the court sentence nor the details obtained from the brief of the People's Procuracy gave any specific details on how Fr. Ly's actions had infringed Article 87 (Amnesty International 2003).

The imprisonment of Fr. Ly prompted condemnation of the Vietnamese state by Viet Kieu groups and by human rights organisations. The Free Vietnam Alliance claimed that

[w]ith world attention focused on the international fight against terror, the Vietnamese authorities quietly brought Father Nguyen Van Ly to trial in a closed-door proceeding without the presence of a defence lawyer or independent witness. Father Nguyen Van Ly had peacefully called on the Vietnamese authorities to respect religious freedom. His efforts received the support of Vietnamese and international friends...The harsh sentence against [him] is part of an escalating pattern of religious and human rights repression over the last five months (Free Vietnam Alliance 2001).

Archbishop George Pell of Sydney wrote to Vietnam's ambassador to Australia that

I formally protest Fr. Ly's arrest, and the long campaign of persecution and harassment that he and others working for religious freedom in Vietnam have suffered at the hands of the authorities ('Archbishop calls for release of Viet priest', Catholic Weekly, 5 September 2001:n.p.). 
Unsurprisingly, the Vietnamese authorities repudiated these claims, stressing that Fr. Ly had committed non-religious crimes. A 'Voice of Vietnam' report concluded that

[i]nstead of focusing on religious activities, Nguyen Van Ly repeatedly broke the law, and was punished several times. Recently, Nguyen Van Ly conducted activities that disrupted public order, incited people to act against the administration, and undermined public order and security...He also urged his disciples to stage disruptive activities in the Truyen Nam Hamlet, and at the office of the Phu An commune People's Committee, frustrating local people and Catholic followers (Voice of Vietnam 2001:n.p.).

What lessons are to be learned from the case of Fr. Ly? First, his prosecution exemplifies how the explicit constitutional provision guaranteeing religious freedom can be made meaningless by the use of other, contrary, provisions. Some accuse the Vietnamese state of manipulating the legal process by applying national security laws to stifle religiously motivated dissent. Fr. Ly was, after all, a religious leader, who, in his antigovernment pronouncements, was conducting a campaign with a specifically religious purpose-to ensure religious freedom and tolerance for the Vietnamese Catholic community and beyond.

Such an impression is only accentuated by the vague, indeterminate and subjective nature of the national security provisions in Chapter XI of the criminal code generally, and Article 87 in particular. What does it mean to 'undermine the people's power'? What does it mean to 'sow division amongst social strata', or to 'sow division between the people's power and social organisations'? It is difficult to avoid the instrumentalist conclusion that they mean whatever suits the Party and government at any given time, convenient for silencing anyone, religious or otherwise, who would seek to speak out against those in power. Those who seek to condemn the Vietnamese government for their prosecution of Fr. Ly could argue that, in construing the provisions of Article 87, the People's Court of Thua ThienHue had no recourse to definitional provisions contained within the legislation or to precedents in the interpretation of the provision. In seeking a determinative outcome, the parties had no recourse to a Constitutional Court to determine whether the provisions of Article 87, as used in Fr. Ly's case, breached the guarantee of religious freedom provided in Article 70 of the Vietnamese Constitution of 1992, and was hence ultra vires. Such antagonists argue that the cumulative effect of these deficiencies provide for an arbitrary and manipulable application of the legal provisions, effectively negating the constitutional provision on religious freedom. This is precisely the position adopted by Amnesty International in naming Fr. Ly a prisoner of conscience (Amnesty International 2003).

But the Vietnamese government is not the only actor that can manipulate the uncertainty surrounding the provisions of the criminal code. It must be remembered that, amongst his many other actions, Fr. Ly wrote to the legislature of a foreign state (the United States), asking that they not enter into a bilateral trade agreement with his own government.

I happen to share two characteristics with Fr. Ly. First, I am a Catholic diocesan priest, and second, I am a citizen of a nation that recently negotiated a bilateral trade 
agreement with the United States (namely, Australia). If I were to write a widely publicised letter to the United States Congress asking that they not enter into a trade agreement with Australia, I am sure the Australian government would not take the least bit of notice. I am equally sure, however, that I would receive immediate, and possibly punitive, attention from my own diocesan authorities. The reason is that I would be seen to have strayed into areas of party-politics and public policy, which is outside my public role as a cleric, since they are not matters of a religious nature, even when that term is broadly construed.

Now, lest it be thought that I am criticising Fr. Ly for his pronouncements, or supporting the Vietnamese government for the action taken against him, I make it clear that I am doing neither. As Amnesty International stated, Fr. Ly was imprisoned solely for the peaceful expression of political beliefs (Amnesty International 2003). I do, however, suggest that there is a certain element of disingenuousness on the part of Fr. Ly's supporters in suggesting that he has been imprisoned for religious reasons, and that the action against him was part of a wider campaign to eradicate religion generally, and the Catholic Church in particular. It must be remembered that the dispute over the Nguyet Bieu lands, and his earlier letters of protest calling for religious freedom, resulted only in a house arrest. Whilst some would regard this result as iniquitous and unjust in a democratic pluralist society, it was only Fr. Ly's venture beyond religion and into party-politics that prompted the Vietnamese government to prosecute him under the criminal code. The mere fact that an act or statement comes from a religious figure does not make it ipso facto a religious act. Other Catholic dissidents—notably the Redemptorist priest, Fr. Chan Tin—have been no less persistent in their criticism of the government and their calls for religious freedom. Yet in recent years, none have been so harshly punished as Fr. Ly, perhaps because none have ventured so far into the political realm.

Fr. Ly's supporters are able to claim that the vagueness of the code's national security provisions enables the government to manipulate them against religion and religious figures. It is this very same vagueness that enables them to claim that he was prosecuted for his religious beliefs, when his actions were in fact not strictly religious, but political. Again, the treatment meted out to Fr. Ly would be rightly seen in any democratic pluralist society as an unacceptable restriction on political freedom. However, Fr. Ly's supporters can now portray him as a religious 'martyr' — a figure deeply symbolic and heroic to Catholics generally, and to Vietnamese Catholics in particular (see Hansen 2000). They point to his extended prison sentence as an example of religious persecution, when it is in fact the consequence of a specifically political action. This suggests that the Vietnamese Communist Party and state are not the only ones capable of manipulating the laws to obtain a desired political outcome. ${ }^{33}$

Furthermore, the government now seems under pressure to ensure that actions taken against religious leaders follow due process in accordance with the criminal sanctions prescribed by the law. In 1999, a Jesuit priest, Fr. Joseph Nguyen Cong Doan, imprisoned on dubious charges for many years, told the Catholic Journal America that 
[t]he approach of the Government has softened somewhat in regard to religious figures who are accused in this way; the policy is now to try to settle the matter without a trial and incarceration. Agents of the Ministry of Public Security can no longer act with as much impunity as they did in the 1980s, arresting anyone whom they suspected and imprisoning them. Now they take much more care to follow legal procedures ('An interview with Joseph Nguyen Cong Doan', America, 23 October 1999).

\section{RELIGIOUS FREEDOM-ALL OR NOTHING?}

If the preceding analysis suggests that the law does not provide a complete basis for religious freedom for the Catholic Church in Vietnam, what is to be made of the competing 'fundamentalism' referred to at the start of this chapter, which argues that there is no real religious freedom in Vietnam at all? In other words, are we to conclude that these are contrasting ideas that cannot be reconciled? Or are there gradual differences between theory and practice?

In a 2002 critique of the state of religious freedom in Vietnam, a VietnameseAmerican priest, Fr. Tran Xuan Tam, wrote

The VCP [Vietnamese Communist Party], using these relaxations and permissions, deceitfully causes in the mind of many superficial and inexperienced Western observers the impression that the Catholic Church in Vietnam today has a true religious freedom, though it may not be complete with respect to certain areas...However, this impression must be discarded as a false one. Religious activities cannot be mistaken for religious freedom, at least in the context of a country ruled by totalitarianism like the VCP [sic]. In this context, religious freedom for the Church must mean that she is completely independent of the Party and truly self-governing or autonomous in her own organisation, and in all her religious activities. Then religious freedom is not identical to the existence, kind and number of religious activity. Religious freedom is rather an intrinsic quality which every religious activity should have. No religious freedom can exist without religious activity, but there can be religious activities without religious freedom. Thus understood, it is obvious from my foregoing analysis that the religious freedom of the Vietnamese Catholic Church is still suppressed in essence by the Party (Tran Xuan Tam 2002).

There are several highly problematic aspects to this analysis. First, Tam concedes no credence to the legal rights granted to religious freedom and practice in Vietnam at present; even though underlying restrictions on the church remain in place, Tam contends these permitted activities do no more than create an illusion of freedom.

But drawing this radical dichotomy between religious freedom and religious activity makes no inherent sense. That Vietnamese Catholics can attend mass, receive the sacraments, read the scriptures, catechise their children, and be shepherded by bishops in union with the universal church, is no mere illusions. These activities are, for Catholics, very real and demonstrable aspects of their faith life in action. These activities demonstrate a degree of legal religious freedom that has continued to widen over recent years. To accept Tam's viewpoint is to regard the improvements in the church's situation since the late 1980s as illusory and insignificant. Yet, for Vietnamese Catholics, they are neither.

This, however, by no means suggests that religious freedom in Vietnam is complete. Insofar as religious activities remain tightly controlled by administrative law, and criminal law is applied against religious figures on spurious allegations 
of criminality, neither the Catholic Church nor other Vietnamese religions can be satisfied that their religious freedom is complete. But Tam's 'all or nothing' approach to religious freedom is deeply problematic. To contend simply that any restriction on religious freedom implies no freedom at all is to ignore the real improvements made in relationships between the church and the Party/state, and the increased tolerance the church has experienced over recent years. These improvements should not be overlooked, even if the Vietnamese state still seeks to control and to limit the church and its concessions are not granted out of a sense of affection and trust. If Vietnam were the 'totalitarian' state that Tam believes it is, surely even these concessions would not have been made. The description by Professor Carlyle Thayer-that 'Vietnam today is best described as an authoritarian state, not a totalitarian one' - is surely to be preferred (Thayer 2001:n.p.).

Tam's portrayal of the church as presently suffering from a crushing burden of totalitarian persecution —in effect, a sort of institutional martyrdom - must be viewed within its historical context. The Vietnamese Catholic Church's identity is deeply rooted in its suffering at the hands of persecutors over many centuries, a suffering which it believes has strengthened and sanctified it. Conversely, the historical antecedents of the Catholic Church, with their association with colonialism, partypolitical intriguing, and virulent anticommunism, have significantly conditioned the attitudes of the Vietnamese Communist Party/state towards it. The party-state's attitude to religion - and especially to Catholicism - is fundamentally formed by the historical experience of religion in Vietnam, and in particular by institutional religion's attitude towards nationalist and revolutionary struggles.

It is true that the doctrine of collective mastery-an inherent part of Marxist regimes-precludes alternative mass organisations, and that the Catholic Church can be seen as the mass organisation in excelsis. This has probably been a major factor in the Fatherland-Front endorsed Union of Patriotic Catholics' assumption of many functions-particularly in the realms of publishing and communicationthat would be reserved for the church hierarchy in other societies. However, the reasons for this are not unrelated; again, the historical relationship can account for this development as much as the doctrine of collective mastery.

In most Party-sponsored analyses of Catholicism, little attention is paid to the truth or untruth of its spiritual or theological claims. What is canvassed at length is the negative historical antecedents of Catholicism in Vietnam, which led it to become (by this analysis) a tool of oppression, first in the hands of the ruling class, later in the hands of external colonial forces. In this context, Catholicism has been portrayed as the most reactionary and counter-revolutionary of all the religions practiced in Vietnam.

But some within the church can now claim that it is itself a victim of oppression, and is thus on the side of the oppressed, rather than oppressors. This is a direct challenge to the government's contextualising the merits of the Vietnamese church entirely in political and historical terms, without making allowance for either its spiritual dimension or its social contribution below the level of institutional politics. 
It is therefore more than theoretically significant that, in recent years, statesponsored journals have begun to publish articles praising the contribution of the Catholic Church to Vietnamese historical and contemporary culture and society (cf. Nguyen Hong Duong 1993; Huy Thong 2001). ${ }^{34}$ These suggest a real acceptance of the Catholic Church's legitimacy in Vietnam, and even a concession to the church being a positive social force. ${ }^{35}$ Such acceptance may in future be incorporated into the legal system, both in terms of legislative and quasi-legislative provisions, and the manner in which they are interpreted and applied.

The Vietnamese Catholic Church remains dissatisfied with the level of legal control exerted over it by the state, and it has reason to do so. This chapter, however, has demonstrated that recent changes have been largely positive. There are sound reasons for believing that these trends will continue if both sides can shake off the shackles of mutual historical antagonism.

\section{NOTES}

1 The legal situation of the Catholic Church in Vietnam, whilst distinguishable from that of other religions on some points, is sufficiently parallel to those religions that the conclusions drawn here have significant applicability to them. I have chosen to use the Catholic Church as an example of interaction between church and state, as I have a better grounding in its situation, and a greater access to sources, than with other Vietnamese faiths.

2 All quotations from the Vietnamese Constitution are taken from the English translation (Government of Vietnam 2001) available at http://vietforum.org/English/Documents / doc16.htm [accessed 31 March 2003]. Amendments to the constitution passed in 2001 did not directly affect Article 70 .

3 Constitutions were promulgated in 1946, 1959, 1980, and 1992 respectively. For a brief history of the successive Vietnamese constitutions, see Sidel (2002).

4 Quoted in Nguyen Quang Minh (2001:110).

5 Indeed, it was initially Msgr. John Dooley, the Apostolic Delegate to Hanoi, rather than the Vietnamese state, who declared in 1955 that no Catholic could in good conscience belong to both the church and the 'Patriotic Association' (Denney 1990:274). Whilst this injunction is no longer in force, it is generally believed that only a minority of Vietnamese Catholics are affiliated to the Patriotic Association's successor.

6 For example, Associated Press reported in 2001 that 'Relations between Vietnam and the Vatican are strained because Hanoi keeps religious groups on a tight leash, and reserves the right to appoint Catholic bishops. Under Catholic canon law, the right to appoint bishops is reserved to the Pope, although the right to internal consultation is also provided to some national churches' ('Vietnam reacts coolly to naming of new Vietnamese Cardinal', 22 February).

7 Under the church's Canon Law (Canon 1382), any bishop ordained without the permission of Rome is illicitly ordained, and both the new bishop and the ordaining bishop are subject to excommunication (Canon Law Society of Great Britain and Ireland 1984).

8 In March 1946, the head of the 'Young Catholic Workers' Movement', Nguyen Manh Ha, was appointed as Minister of Economics. The Bishop of Phat Diem, Le Hu Tu, was appointed a 'senior advisor' and member of the High Council (Gheddo 1968:25).

9 Sidel goes on to call for a much broader frame of reference in interpreting the Vietnamese constitution than the narrow confines of instrumentalism.

10 For a discussion of the attempts to delete or amend Article 4 at the time of the 2001 constitutional amendments, see Sidel (2002).

11 Various charismatic sects may perhaps be less fortunate. So might charlatans, such as the group that allegedly tried to create apparitions of the Blessed Virgin Mary using laser lights ('Vietnam names three over fake religious apparitions', Reuters, 27 October 1999). Historically, the state's view of Catholic practice was less favourable. Elaborate, lengthy and costly liturgical 
and devotional practices were regularly described as 'superstitious', and in some cases restricted or prohibited by local cadres. It was eventually the liturgical reforms of the Second Vatican Council, rather than government intervention, which saw these practices curtailed.

12 All references to the 1999 Criminal Code are from Government of Vietnam (2001b). Disapproval of such practices would also accord with official Catholic doctrine, if not with Catholic folk practice.

13 The pronouncement seems to have been made in response to unlicensed Protestant Churches working amongst ethnic minorities in the Central Highlands.

14 Foreigners, and many of the Viet Kieu, were effectively prevented from attending. I applied for, and was denied, a visa to attend.

15 Government attitudes to the event changed considerably as it reached its climax. The tone of official pronouncements became more favourable as time passed; they were, perhaps, eventually satisfied that the gathering constituted no political threat.

16 This becomes clearer in the introductory provisions to Decree 26/1999 on Religious Activities.

17 To the best of my knowledge, this now happens rarely if ever.

18 Social policy questions can also bring church and state into happier alignment. The Vietnamese government has praised the Catholic Church for being in the vanguard of the campaign against 'social evils'.

19 The Catholic proportion of the Vietnamese population is difficult to determine with precision (Cong Giao va Dan Toc [Catholicism and the Nation] Magazine 1995).

20 All English translations of Party Directive 37 and State Decree 26 are taken from Nguyen Minh Quang (2001:125-46). The directive goes on to provide for the establishment of a governmentcontrolled religious publishing house (2001:132).

21 There is some recourse to legal precedent within the Vietnamese legal system, but of only very limited effect. The Vietnamese system shares this characteristic not only with legal systems in other socialist countries, but also other civil law jurisdictions, including those of most western European nations.

2 This permission is presently provided to six churches: the Roman Catholic Church, the Confederation of Evangelical Alliances (representing Protestants), the Buddhist Church of Vietnam, and peak bodies representing the Cao Dai, Hoa Hao and Islamic faiths.

23. Hence the reference in the Party Directive to the establishment of a state religious publishing house.

24 Considerable progress, however, was made in this issue during 2002-3, with several important diocesan vacancies being filled.

25 This problem does not prevent the publication of bibles, prayer books, liturgical texts and devotional works, all of which are regularly licensed. Its effect is largely to restrict publications regarding church affairs, which remain the domain of the 'Solidarity Committee of Patriotic Catholics', particularly through their weekly magazines Nguoi Cong Giao ['Catholics'] in Ha Noi, and Cong Giao va Dan Toc ['Catholicism and the People'] in Ho Chi Minh City.

26 The spokeperson for the Vietnamese Foreign Affairs Department, Phan Thuy Thanh, employed a well-worn (and technically correct) phrase in telling foreign reporters that 'In Vietnam, no-one is detained on religious grounds, there are only law violators who are punished' ('Vietnam denies persecution of Hill Tribe People', Deutsche Presse-Agentur, 23 January 2003:n.p.).

27 Untitled press release of the Free Vietnam Alliance, 6 December 2000. The Free Vietnam Alliance is a US-based organisation of overseas Vietnamese, associated with the pre-1975 republican government, who seek the overthrow of the current regime.

28 The statement and letter are available at http://www.fva.org [accessed 15 January 2001].

29 Fr. Ly went on to discuss, amongst other matters, the record of Ho Chi Minh, whom he came close to branding a war criminal.

30 An English translation of the decision is available at http:/ /www.fva.org [accessed 3 June 2001].

31 English translation of decision at www.fva.org, last accessed 3 June 2001.

32 The sentencing of Ly was televised nationally by the state-owned VTV ('Vietnam sentences Catholic priest', Associated Press, 19 October 2001).

33 Interestingly, three strident Catholic critics of the Vietnamese government's attitude to religious freedom, writing at or after the time of Fr. Ly's case, all failed to mention him in their catalogue of complaints of religious intolerance (Tran Cong Nghi 2001; Tran Xuan Tam 2002). 
34 Previous praise of Catholicism was confined to the political role of 'patriotic Catholics' who showed their nationalist antecedents by opposing the feudalists, the colonialists (that is, the French), or the imperialists (namely, the Americans).

35 Particularly in relation to the church's strong support for the government's 'social evils' campaign.

\section{REFERENCES}

Amnesty International, 2003. Socialist Republic of Viet Nam - The Espionage Case Against the Nephews and Niece of Father Thadeus Nguyen Van Ly. Available from http:/ / web.amnesty.org/library/index/engasa410042003 [Accessed 8 April 2003].

Amor, A., 1998. Civil and Political Rights, Including the Question of Religious Intolerance: Vietnam (English edition), Available from http://www.vnhrnet.org/english/ documents/amoren.htm [Accessed 25 March 1999].

Brunnstrom, D., 2000. 'Archbishop says Vietnam Catholics Face Problems', Reuters, 16 November.

Bureau of Democracy, Human Rights, and Labor, 2000 Annual Report on International Religious Freedom, Bureau of Democracy, Human Rights, and Labor, US State Department, Washington, DC. Available online at http:/ / www.state.gov/www / global/human_rights/irf/irf_rpt [Accessed 22 September 2000].

Canon Law Society of Great Britain and Ireland, 1984. The Code of Canon Law in English Translation, Collins, London.

Cong Giao van Dan Toc [Catholicism and the Nation] Magazine (eds), 1995. 'Cong Giao Viet Nam Sau Qua Trinh 50 Nam, 1945-1995 [Vietnamese Catholics after a process of fifty years]', Cong Ciao va Dan Toc Magazine.

de Nerciat, C-A., 2000. 'Vietnamese Catholics mark Easter with fervour, defiance', Agence-France Press, 23rd April.

Denney, S., 1990. 'The Catholic Church in Vietnam', in P. Ramet (ed.), Catholicism and Politics in Communist Societies, Duke University Press, Durham, North Carolina.

Free Vietnam Alliance, 2001. 'An Appeal to Oppose Communist Vietnam's Policy of Terror', Free Vietnam Alliance, Anaheim Hills, California, 19October .

Gheddo, P., 1968. The Cross and the Bo Tree, Sheed \& Ward, New York [tr. Charles Quinn].

Government of Vietnam, 2001. Constitution of the Socialist Republic of Vietnam, Government of the Socialist Republic of Vietnam, Hanoi (English Translation). Available from http://vietforum.org/English/Documents/doc16.htm [Accessed 31 March, 2003].

— 2001. Bo Luat Hinh Su [Criminal Code], Government of the Socialist Republic of Vietnam, Hanoi. Available from http:/ / www.vietlaw.gov.vn [Accessed 8 April 2003].

Hansen, P., 2000. Making Martyrs: a study in Vietnamese church-state conflict, MA thesis, Monash University, Melbourne, unpublished. 
Haub, C., and Phuong Thi Thu Huong, 2003. An Overview of Population and Development in Vietnam, National Committee for Population and Family Planning, Hanoi.

Human Rights Watch, 1997. Rural Unrest in Vietnam, Available from http:/ / www.hrw.org/reports/1997/vietnm/Vietn97d-03.htm [Accessed 1 April 2003].

Huy Thong, 2001. 'Interrelation between Catholic and Vietnamese culture', Social Sciences, 82:73.

Nguyen Hong Duong, 1993. 'Integration process of Catholicism into the national culture', Social Sciences, 74:63.

Nguyen Minh Quang, 2001. Religious Problems in Vietnam, The Gioi Publishers, Hanoi.

Nguyen Van Ly, 2000. Letter to Pope John Paul II, 12 January. Available from http:/ / www.fva.org [Accessed 15 January 2001].

——, 2001a. Letter to Various Dignitaries, 26 December. Available from http:/ /www.fva.org [Accessed 9 January 2001].

_ 2001b. Letter of Testimony of Fr. Ly to US Congress Committee on International Religious Freedom, 13 February 2001, US Congress, Washington, DC. Available online at http:/ / www.uscirf.gov.

Sidel, M., 2002. 'Analytical Models for Understanding Constitutions and Constitutional Dialogue in Socialist Transitional States: Re-Interpreting Constitutional Dialogue in Vietnam', Singapore Journal of International and Comparative Law, 6:42-98.

Soloman, A., 1998. 'Vietnam Party chief says thrift before religion', Reuters, 5 May.

Thayer, C., 2001. Statement to the Hearing on Religious Freedom Violations in Vietnam, US Commission on International Religious Freedom, Washington, DC, 13 February. Available from http:/ / www.uscirf.gov [Accessed 16 February 2001].

Tong, J., 1993. 'The church from 1949 to 1990 ', in E. Tang and J-P. Wiest (eds), The Catholic Church in Modern China, Orbis Books, Maryknoll, New York:7-27.

Tran Cong Nghi, Rev. John, 2001. Letter of Testimony to the Unites States Commission on International Religious Freedom, 13 February. Available online at http:/ / www.uscirf.gov.

Tran Xuan Tam, Rev., 2002. An Analysis of the Vietnamese Communist Party's Suppression of the Religious Freedom of the Catholic Church, Archdiocese of Washington, DC. Available online at htpp://vietpage.com/archive_news/politics/2002/Sep/ 30/0152.html [Accessed 29 September 2002].

Voice of Vietnam, 17 May 2001. ‘Vietnam Arrests Catholic Priest for Defying House Arrest Order', BBC Monitoring Service. 